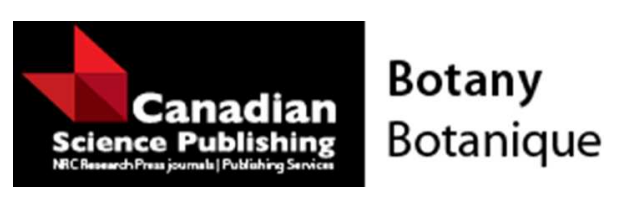

\title{
Seasonality affects phytotoxic potential of five native species of Neotropical savanna
}

\begin{tabular}{|r|l|}
\hline Journal: & Botany \\
\hline Manuscript ID & cjb-2015-0124.R2 \\
\hline Manuscript Type: & Article \\
\hline Date Submitted by the Author: & $29-$ Oct-2015 \\
\hline Complete List of Authors: & $\begin{array}{l}\text { Pinto, Graciele; Univ Estadual Paulista, Ciências Biológicas } \\
\text { Kolb, Rosana; Univ Estadual Paulista, Ciências Biológicas }\end{array}$ \\
\hline Keyword: & $\begin{array}{l}\text { allelopathy, Cerrado, aqueous extracts, phytochemical screening, } \\
\text { secondary metabolism }\end{array}$ \\
\hline \multicolumn{2}{|l}{} \\
\hline
\end{tabular}

SCHOLARONE $^{\text {Im }}$

Manuscripts 
Seasonality affects phytotoxic potential of five native species of Neotropical savanna

\author{
Graciele Fernanda de Souza Pinto, Rosana Marta Kolb* \\ Department of Biological Sciences, Faculty of Sciences and Letters, Univ Estadual Paulista - \\ UNESP. Av. Dom Antônio, 2100, 19806-900, Assis, São Paulo, Brazil
}

\title{
E-mail addresses:
}

Graciele Fernanda de Souza Pinto gracinanda@hotmail.com

Rosana Marta Kolb rosanakolb@hotmail.com

* Corresponding author's e-mail address: rosanakolb@hotmail.com 
Abstract: Phytotoxic secondary metabolites produced by plants have been studied as possible sources of bioherbicides. However, several environmental factors can change the secondary metabolism of plants and thus, the production of these compounds. Among these factors, seasonality can cause variations in the content of all classes of secondary metabolites. In this study, we evaluated the phytotoxic effect of aqueous extracts of leaves from Byrsonima intermedia, Gochnatia polymorpha, Luehea candicans, Miconia chamissois and Qualea cordata (species of the Brazilian savanna), collected both during the dry and the rainy season, on germination and seedling growth of maize and cucumber. The analysed parameters were affected by all leaf extracts collected during both seasons. However, a greater phytotoxic effect was observed when leaves were collected during the dry or during the rainy season, depending on the savanna species studied, on the target species and parameters evaluated. The phytochemical screening of all extracts was also evaluated and allowed the identification of anthraquinones, triterpenoids, saponins and tannins. The composition of extracts differed between the seasons for all species. This study highlights the importance of considering savanna seasonality when studying the phytotoxicity of the species of this biome.

Key words: allelopathy, Cerrado, phytochemical screening, secondary metabolism, aqueous extracts. 


\section{Introduction}

Bioactive plant compounds are sources for the development of new chemical compounds, which are important for pharmaceutical, medical and agronomic areas, among others. In agronomy, phytotoxic bioactive compounds are used as templates for the development of new natural herbicides that are less toxic to the environment (Duke et al. 2000). The search for these bioactive compounds has increased the interest in secondary metabolites derived from chemical communication between organisms (Macías et al. 2008) or those that are responsible for the protection of plants against other plants, insects and herbivores (Pinto et al. 2002).

Studies have shown that plants submitted to biotic or abiotic stress produce large amounts of bioactive compounds (Chaves and Escudero 1999; Gobbo-Neto and Lopes 2007). The Brazilian Cerrado, the largest savanna in South America, is a promising resource in the search for these bioactive compounds. The Cerrado is one of the most biodiverse vegetation formations in Brazil, where plants are strongly influenced by limitations of rainfall regime, high temperatures, high irradiances and nutrient-poor soils with high levels of aluminum (Franco 2002; Gottsberger and Silberbauer-Gottsberger 2006), and fire (Hoffmann 1996). The climate of this biome is markedly seasonal, with a dry period from May to September (Gottsberger and Silberbauer-Gottsberger 2006). Rainfall is concentrated in the summer and annual precipitation ranges from 800 to about $2,000 \mathrm{~mm}$ and the mean annual temperature ranges from 20 to $26^{\circ} \mathrm{C}$ (Eiten 1972). Considering the rainfall seasonality of the Cerrado, water deficit in the surface layers of the soil and a high atmospheric evaporative demand are key factors for plants that grow there (Sarmiento 1996; Franco 2002; Bucci et al. 2008). Critical physiological processes such as photosynthesis, reserve mobilisation, resource allocation patterns and plant growth are affected by water limitation, triggering changes in plant secondary metabolism (Taiz and Zeiger 2009). Therefore, water limitation can alter the production of many secondary metabolites, depending on the period in which drought occurs 
and whether it is of short or long duration (Gershenzon 1984; Horner 1990; Jung 2004). Studies on the phytotoxicity of Cerrado species have increased (Gatti et al. 2004; Silva et al. 2006); however, few studies have focused on seasonality effects of the Cerrado on the phytotoxic potential of native species (Gatti et al. 2014), which remains poorly understood. The species selected for this study are abundant in the Cerrado and have biological activity (Barros et al. 2006) or are used in popular medicine (Carvalho 2003; Stefanello et al. 2006; Negrelle 2011; Santos et al. 2012). Many medicinal plants have phytotoxic potential (Fujii et al. 2003; Alves et al. 2011; Silvestre et al. 2013), indicating that these might be good candidates to be studied among the species that occur in the Cerrado. Thus, we investigated the phytotoxicity of leaf extracts of five Cerrado species and the effect of seasonality (dry and rainy season) on their phytotoxic potential. We also did a preliminary assessment of the composition of secondary metabolites in leaves collected both during the dry and during the rainy season.

\section{Materials and Methods}

\section{Plant materials}

Leaves of Byrsonima intermedia A. Juss. (Malpighiaceae), Gochnatia polymorpha (Less.) Cabrera (Asteraceae), Luehea candicans Mart. (Tiliaceae), Miconia chamissois Naudin (Melastomataceae), and Qualea cordata Spreng (Vochysiaceae) were collected in August 2013 (dry season) and April 2014 (rainy season) in the Cerrado at the Ecological Station of Assis, municipality of Assis, São Paulo state, Brazil (22³3'20” to $22^{\circ} 37^{\prime} 41^{\prime \prime}$ S and $50^{\circ} 24^{\prime} 48^{\prime \prime}$ to $\left.50^{\circ} 21^{\prime} 27^{\prime \prime} \mathrm{W}\right)$. Leaves of G. polymorpha and L. candicans were collected at the edge of the cerradão phytophysiognomy, leaves of $B$. intermedia and $Q$. cordata were collected in the cerrado stricto sensu, and leaves of M. chamissois were collected in swampy areas. The cerradão is composed of trees up to $15 \mathrm{~m}$ high, which form a continuous canopy; 
grasses are absent. The cerrado stricto sensu is characterised by shrub vegetation with scattered trees and a discontinuous canopy cover (Durigan et al. 1999). Leaves were collected from at least five randomly chosen individuals for each species and in each season. All individuals were adult, over $15 \mathrm{~cm}$ in diameter at breast height (for the tree species $G$. polymorpha, L. candicans and Q. cordata) or over $5 \mathrm{~cm}$ in diameter at the stem base (for the shrub species $B$. intermedia and $M$. chamissois), and were sampled in the same region with a minimum distance of $5 \mathrm{~m}$. All individuals were exposed to similar light conditions, and healthy and completely expanded leaves were collected from the third and fourth nodes. At least 30 leaves were collected per individual; these were dried in the shade, and ground in a Wiley mill. Leaf powder was stored in polyethylene containers and kept at $4{ }^{\circ} \mathrm{C}$ until use.

\section{Preparation of extracts}

Extracts were obtained in the ratio of $1: 10 \mathrm{w} / \mathrm{v}$ (plant material:distilled water), and were maintained at rest at $4^{\circ} \mathrm{C}$ for $24 \mathrm{~h}$ in the dark (Borghetti et al. 2013). Subsequently, the extracts were filtered through $14-\mu \mathrm{m}$ porosity qualitative filter paper, from Qualy®. An aliquot of the extracts was evaporated to dryness and their yields were calculated. The remainder of the extracts were stored in polyethylene containers and frozen until use.

\section{Physical-chemical characteristics of the extracts}

Measurement of $\mathrm{pH}$ and its influence on the target species

The $\mathrm{pH}$ of the aqueous extracts (ratio of $1: 10 \mathrm{w} / \mathrm{v}$ ) was measured using a $\mathrm{pH}$ meter (TEC-2, Tecnal, Brazil). Toxicity tests with an aqueous solution acidified with $0.1 \mathrm{~N} \mathrm{HCl}$ were performed to assess the influence of the lowest $\mathrm{pH}$ value obtained from the extracts (3.69, see Table 1) on the parameters of germination and early growth of maize and cucumber. This analysis is important, because germination and seedling development are 
adversely affected by acidic conditions (Eberlein 1987), which might result in a phytotoxic effect similar to that of bioactive compounds.

\section{Osmotic potential measurement}

The osmotic potential of extracts was determined with an Abbe refractometer, from osmotic solutions obtained using PEG 6000 (Villela et al. 1991), with osmotic potentials of 0.001 to $-0.01 \mathrm{MPa}$ and was calculated according to equation (1):

$$
y=-3.7765 x^{2}-10.237 x+0.195
$$

where: $y=$ Refractive Index in (Brix).

The osmotic potential of extracts was evaluated because it can mimic phytotoxic effects (Wardle et al. 1992; Ferreira and Aquila 2000); at osmotic potential values more negative than -0.9 MPa, germination is severely reduced, and at values more negative than 1.5 MPa, germination is totally inhibited (Eberlein 1987).

\section{Target species}

Bioassays were conducted with long green cucumber (Cucumis sativus L.) and double hybrid maize SHS 4080 (Zea mays L.) to evaluate the phytotoxic potential of extracts on their germination and early growth. Because phytotoxic effects can be species-dependent (Ferreira and Aquila 2000), two target species were selected; one eudicot and one monocot, respectively. Cucumber and maize were selected because they display high, rapid and uniform germination, rapid early growth, and a high sensitivity that allows effects at low concentrations of bioactive compounds to be observed (Rice 1979; Ferreira and Aquila 2000).

\section{Germination bioassay}


Experiments were performed in germination boxes $(11 \times 11 \times 3.5 \mathrm{~cm})$, containing two sheets of wetted filter paper with $10 \mathrm{~mL}$ of extracts for bioassays conducted with cucumber seeds and $15 \mathrm{~mL}$ of extracts for bioassays conducted with maize, or distilled water for the control. Each treatment consisted of five replicates containing 20 seeds of cucumber or maize $(\mathrm{n}=100)$. Germination boxes were kept in a BOD incubator (Eletrolab, model 102 FC) at $25^{\circ} \mathrm{C}\left( \pm 1^{\circ} \mathrm{C}\right)$ with a photoperiod of $12 \mathrm{~h}$. Seed counting was performed every $12 \mathrm{~h}$, totalling $96 \mathrm{~h}$ for maize seeds and $120 \mathrm{~h}$ for cucumber. Seeds were considered to have germinated when $1 \mathrm{~mm}$ of the root protruded. The parameters analysed were germination ability at the end of the observations (equation 2), the speed of germination (equation 3) and synchrony of germination (equation 4). A lower germination ability, a slower speed germination and lesssynchronised germination (high values of synchrony) indicate disruptions to the germination process (Santana et al. 2006).

Eq. 2

$$
\mathrm{G}(\%)=(\mathrm{N} / \mathrm{A}) \times 100
$$

where: $\mathrm{G}(\%)=$ the germination percentage; $\mathrm{N}=$ the number of germinated seeds; $\mathrm{A}=$ the total number of seeds placed to germinate.

Eq. 3

$$
\mathrm{V}=1 / \mathrm{t}
$$

where: $\mathrm{V}=$ the speed of germination (hours $\left.{ }^{-1}\right) ; \mathrm{t}=$ the mean germination time $\mathrm{t}=$ $\sum$ (ni. ti) $/ \sum$ ni, with: $t_{i}=$ the incubation time and $n_{i}=$ the number of germinated seeds in time between two successive observation times $(\mathrm{t}-1)$ and $\left.\left(\mathrm{t}_{\mathrm{i}}\right)\right)$.

Eq. 4

$$
\mathrm{U}=-\sum\left[\mathrm{f}_{\mathrm{i}} \cdot \log _{2}\left(\mathrm{f}_{\mathrm{i}}\right)\right]
$$


where: $U=$ germination synchrony; $f i=$ the relative frequency in time $\left(f i=n i / \sum n i\right.$; with: $f_{i}=$ the relative frequency in time; $n_{i}=$ the number of germinated seeds in time between two successive observation times $(\mathrm{t}-1)$ and $\left(\mathrm{t}_{\mathrm{i}}\right) ; \sum \mathrm{n}_{\mathrm{i}}=$ the number of total germinated seeds).

Note that $U$ actually is lack of synchrony, in that the more synchronous the germination timing, the lower the value of $U$. The advantage of this metric is that its value is not influenced by the total number of germinated seeds. Also, note that log of zero is undefined (Santana and Ranal 2000).

\section{Initial growth bioassay}

Bioassays were performed in germination boxes $(11 \times 11 \times 3.5 \mathrm{~cm})$, containing two sheets of wetted filter paper with $10 \mathrm{~mL}$ of extracts or distilled water (control). Each treatment consisted of three replicates containing 20 germinated seeds (with $2 \mathrm{~mm}$ of root protrusion) of cucumber or maize $(n=60)$. Germination boxes were kept in a BOD incubator under the conditions previously described. The bioassays lasted for $96 \mathrm{~h}$ for maize seedlings and $120 \mathrm{~h}$ for cucumbers. The parameters analysed were the length of the main root and shoot, and the number of secondary roots.

\section{Phytochemical screening}

Aqueous leaf extracts used for the bioassays were subjected to qualitative phytochemical screening by chemical reactions, resulting in the development of colour or precipitate or spume, characteristic for each class of substances. To identify alkaloids, the Hager, Mayer and Dragendorff reagents were used. Anthraquinones were identified with $\mathrm{NaOH}$, coumarins with $\mathrm{KOH}$, and steroids and triterpenoids with $\left(\mathrm{CH}_{3} \mathrm{CO}\right)_{2} \mathrm{O}$ and $\mathrm{H}_{2} \mathrm{SO}_{4}$. To 
identify flavonoids and tannins $\mathrm{AlCl}_{3}$ and gelatin solution were used, respectively (Matos, 1997).

\section{Statistical analysis}

The germination ability, speed of germination, synchrony, length of shoot and primary root and number of secondary roots were calculated as the mean percentage difference compared with the negative control (Chung et al. 2001), according to equation (5):

$$
\text { Percentage difference }(\%)=\left[\frac{\text { control }- \text { extracts }}{\text { control }}\right] \times 100
$$

Positive values represent stimulation and negative values represent inhibition in relation to the control.

The experimental design was completely randomised. The data were tested for normality of the residuals (Shapiro-Wilk test, $p>0.05$ ) and for the homogeneity of the variances (Levene or Cochran test, $p>0.05$ ). All statistical tests were performed on absolute values. Significant differences between treatments were determined using one-way ANOVA followed by Dunnett's test $(p<0.05)$. The data relating to the effect of the extracts and the seasons were analysed by factorial MANOVA followed by Tukey's test for the interaction between factors $(p<0.05)$.

\section{Results}

\section{Yield and physical-chemical characteristics of the extracts}

The yield of the extracts ranged from 0.006 to $0.019 \mathrm{~g} / \mathrm{mL}$ for $Q$. cordata (for leaves collected during the rainy season) and M. chamissois (for leaves collected during the dry season), respectively. The yield of the extracts was higher when the leaves were collected during the dry season, except for L. candicans (Table 1). 
The $\mathrm{pH}$ of distilled water (negative control treatment) was 6.01 , whereas the $\mathrm{pH}$ of the extracts ranged from 3.69 to 6.22 (Table 1). The germination and initial growth of the target species were not affected when tested under the lowest $\mathrm{pH}$ value using an acidified aqueous solution at $\mathrm{pH} 3.69$ (data not shown). The osmotic potential of the extracts ranged from -0.031 to $-0.008 \mathrm{MPa}$ (Table 1), values that are not considered in the phytotoxic range (Eberlein 1987).

\section{Activity of extracts and phytochemistry}

For the germination and growth of maize and cucumber, the Wilks' lambda test showed significance for the leaf extracts, for the seasons and for the interaction between these two factors (Supplementary Table S1). Considering each parameter evaluated for germination and growth of the target species, the statistical analyses reported in Supplementary Table S2 and S3, respectively, showed that significant differences exist among the leaf extracts, between seasons when the samples were collected, and in the interaction between these two factors, except for germination synchronism.

Extracts of $B$. intermedia decreased the speed of germination and the germination synchrony only for cucumber compared with the control. However, there were no significant differences in effects on germination by leaf extracts collected during different seasons (Table 2). In contrast, all seedling growth parameters were lower after treatment with these $B$. intermedia extracts compared to the control, except for maize shoot length (Table 3). The $B$. intermedia leaf extract obtained during the dry season was more phytotoxic to maize growth parameters than that obtained during the rainy season; for cucumber growth, the most phytotoxic leaf extract was that obtained during the rainy season (Table 3). The extract of $B$. intermedia contained a higher concentration of tannins and of triterpenoids in the dry season. 
Anthraquinones were found only in samples collected during the dry season, whereas saponins were found only in samples collected during the rainy season (Table 4).

For G. polymorpha, only the leaf extract obtained during the rainy season inhibited germination, and reduced maize germination ability and the speed of germination of both target species compared with the control (Table 2). All growth parameters studied were lower following treatment with G. polymorpha extracts compared with the control; except for cucumber shoot length that was enhanced after treatment with leaf extract obtained during the rainy season. In general, the leaf extract obtained during the dry season was more phytotoxic to seedlings than that obtained during the rainy season (Table 3). This may correlate to higher concentrations of anthraquinones and triterpenoids in extracts of G. polymorpha in samples collected during the dry season than in those collected during the rainy season (Table 4).

The leaf extract of L. candicans obtained during the rainy season decreased the germination ability of both target species; this extract also decreased the speed of germination and the germination synchrony of cucumber compared with the control (Table 2). Furthermore, the main root of maize was longer when treated with L. candicans extract obtained during the rainy season, whereas its shoot was longer following treatment with the extract obtained during the dry season compared with the control (Table 3). The main root of cucumber did not grow as much, and had fewer secondary roots than in the control following treatment with either the extract obtained during the dry season or the rainy season (Table 3). The extracts of L. candicans contained saponins and tannins in samples collected during both seasons and had a higher concentration of triterpenoids in samples collected during the rainy season (Table 4).

The only effect observed for the M. chamissois extracts on germination was a reduction in the speed of germination of cucumber, in comparison with the control, for the leaf extract obtained during the rainy season (Table 2). In contrast, the extracts of $M$. 
chamissois caused a reduction in all the growth parameters studied; however, maize shoots were longer when treated with the extract obtained during the rainy season (Table 3 ). The $M$. chamissois leaf extract obtained during the dry season was more phytotoxic to all growth parameters than the extract obtained during the rainy season (Table 3). This may correlate to higher concentration of triterpenoids and tannins in samples collected during the dry season than in those collected during the rainy season (Table 4).

The extracts of $Q$. cordata did not affect germination compared to the control (Table 2); however, they caused a reduction in most of the growth parameters of the target species compared with the control (Table 3 ). The leaf extract of $Q$. cordata obtained during the dry season was more phytotoxic than that obtained during the rainy season (Table 3). This may correlate to higher concentration of saponins and tannins in samples collected during the dry season than that obtained during the rainy season (Table 4).

\section{Discussion}

The $\mathrm{pH}$ and osmotic potential of the evaluated extracts per se were not responsible for the observed effects on germination and seedling growth; therefore, the bioassays confirmed that the Cerrado species B. intermedia, G. polymorpha, L. candicans, M. chamissois, and $Q$. cordata are phytotoxic plants. Phytotoxic effects on seeds were observed for most extracts. The decrease in germination ability and the speed of germination, and less synchronised germination indicate disruption of the chemical reactions in the germination process of these seeds (Santana et al. 2006). However, in general, the phytotoxic effects were more pronounced on seedling growth than on germination, corroborating the results of other studies (Ferreira and Aquila 2000; Silvestre et al. 2013).

The effect of secondary metabolites on germination and seedling growth remains unclear. The effect of these metabolites in germination appears to be mediated mainly by the 
disruption of normal cell metabolism and via the mobilisation of reserves, which usually occurs rapidly during the early stages of germination (Gniazdowska and Bogatek 2005). The effects of secondary compounds on seedling growth are diverse and can affect different physiological processes, such as cell division (Silva et al. 2014), photosynthesis (Qian et al. 2009) and respiration (Hejl and Koster 2004; Mushtaq et al. 2013).

The differences in the effects of leaf extracts collected during the dry and rainy seasons of all studied species indicate that seasonality influences the phytotoxicity. Plants usually show a higher phytotoxic potential in the dry season as a result of water stress (Gobbo-Neto and Lopes 2007; Gatti et al. 2014). We observed that a higher phytotoxic potential related to seasonality in Cerrado plants differs, depending on the stage of the target plant life cycle evaluated. For instance, leaf extracts of G. polymorpha and M. chamissois obtained during the rainy season were generally more phytotoxic during germination, whereas the leaf extracts from the dry season of these same species were more phytotoxic to growth parameters. Considering that germination occurs during the rainy season for most Cerrado species (Ranal et al. 2010) and that growth inhibition may hamper the seedlings establishment (Allem et al. 2014), these anti-germination effects in the rainy season and anti-growth effects in the dry season seem to be an optimized strategy to reduce competition under natural conditions in this environment. However, the significant interaction between the different leaf extracts and seasons may at least partially explain the lack of consistent trend across species evaluated.

The effects observed in bioassays of phytotoxicity are the result of different chemical compounds or of different concentrations of these compounds in plants. The phytochemical screenings of the Cerrado plants studied were positive for three or four chemical classes, depending on the species. Some of these chemical classes have been previously reported for these same species, confirming some of our findings: tannins for B. intermedia (Sannomiya et 
al. 2007) and triterpenoids for G. polymorpha (Farias et al. 1984) and for L. candicans (Silva et al. 2012). Previous phytochemical studies of the genus Miconia revealed the presence of some chemical classes in common with the chemical constituents encountered for $M$. chamissois: triterpenoids (Peixoto et al. 2011), tannins and saponins (Gorla and Perez 1997). This reinforces our findings for the species M. chamissois.

Considering all of the species studied, together, there were no clear trends in the seasonality of different compounds; however, the phytochemical analysis suggested a higher concentration of tannins in leaf extracts obtained during the dry season compared to those obtained during the rainy season. Triterpenoids were detected for all five species in leaf extracts obtained both during dry and rainy season; saponins were also detected in all species studied, but not always in the leaf extracts from both seasons. Because extracts did not contain steroids but did contain triterpenoids, the saponins detected in extracts are probably triterpenic. Considering that the leaf extracts of all Cerrado species studied either from both the dry season and the rainy season are phytotoxic, saponins and triterpenoids are good candidates to be potential phytotoxic compounds. Saponins and triterpenoids are recognised as biologically active compounds that affect germination and seedling growth. It has been suggested that saponins reduce the respiratory rate of cotton seeds due to the reduced availability of oxygen diffusion through the integument, which inhibits germination (Marchaim et al. 1974). Several saponins that have been isolated and characterised from other species inhibit the shoot elongation (Scognamiglio et al. 2012) or radicle growth (HernándezCarlos et al. 2011) of plants. It has been proposed that the inhibitory effect of saponins is related to the formation of high-molecular-weight matrices around the radicle, which prevents water uptake by the plant (Waller et al. 1999). Triterpenoids also act as inhibitors of lettuce germination (Martins et al. 2010). In addition, triterpenoids can inhibit the root growth of Echinochloa crus-galli, Amaranthus hypochondriacus and lettuce (González-Coloma et al. 
2011) and stimulate seedling growth in some crop species (Macías et al. 1997), but the mechanism of action of these compounds remains unknown.

Besides considering the effect of seasonality on the phytotoxicity of species, studies that seek to identify bioactive compounds must evaluate different target species, because these can not only exhibit differences in sensitivity (Ferreira and Aquila 2000), but also antagonistic responses. In this study, extracts of L. candicans from samples collected during both seasons favoured the growth of maize and inhibited the growth of cucumber seedlings. Therefore, these extracts contain potential compounds with which to formulate both biofertilizers and selective post-emergent bioherbicides. Extracts of L. candicans obtained during the rainy season also contain potential compounds for the formulation of pre-emergent herbicides. Extracts of B. intermedia from both seasons and extracts of G. polymorpha, $M$. chamissois and Q. cordata from the dry season are good candidates for identifying compounds with a post-emergent herbicide action. Moreover, G. polymorpha extracts, mainly the extract from the rainy season, contain potential compounds that can be used to formulate pre-emergent herbicides. Seedlings of cucumber and maize treated with extracts of $G$. polymorpha and M. chamissois, respectively, obtained during the rainy season, showed longer shoots than the control; however, in these specific cases, this effect might have resulted from a change in the allocation pattern instead of a direct positive affect of the extracts, since the seedlings had longer shoots, although their roots were not as long as the control roots.

In conclusion, this study shows that aqueous extracts of leaves of B. intermedia, $G$. polymorpha, Q. cordata, L. candicans, and M. chamissois possess phytotoxic potential. Their phytotoxic effect, as well as the amount and composition of their secondary metabolites, differ seasonally, probably playing a role in the community ecology of the Cerrado system. Additional research is required to clarify the seasonal regulation of the secondary metabolites 
and exactly how they are involved in the observed phytotoxic effects, to evaluate them better as potential new sources of bioherbicides.

\section{Acknowledgments}

The authors acknowledge the Forestry Institute of São Paulo State for allowing the leaf collections at Assis Ecological Station, and the company Santa Helena Sementes, by donation of maize seeds. This study was supported by grant No. 2013/14413-5, Fundação de Amparo à Pesquisa do Estado de São Paulo (FAPESP).

\section{References}

Allem, L.N., Gomes, S.A, and Borghetti, F. 2014. Pequi leaves incorporated into the soil reduce the initial growth of cultivated, invasive and native species. An. Acad. Bras. Ciênc. 86: 1761-1768. http://dx.doi.org/10.1590/0001-3765201420130420.

Alves, L.L., Oliveira, P.V.A., França, S.C., Alves, P.L.C., and Pereira, P.S. 2011. Atividade alelopática de extratos aquosos de plantas medicinais na germinação de Lactuca sativa L. e Bidens pilosa L. Rev. Bras. Pl. Med. 13: 328-336. Available from http://www.scielo.br/pdf/rbpm/v13n3/a12v13n3.pdf [Accessed 18 September 2015].

Barros, M.T.P., Nasser, E.F., Candido, T.F., Ferreira, W.A., and Paula, A.C.C.F.F. 2006. Avaliação da atividade antimicrobiana de plantas de Miconia ligustroides e Miconia chamissois (Melastomataceae). In Proceedings of the I Simpósio de Pesquisa e V Semic Seminário de Iniciação Científica da Unifenas, Alfenas, M.G., 4 - 6 October 2006.

Borghetti, F., Lima, E.C., and Silva, L.C.R. 2013. A simple procedure for the purification of active fractions in aqueous extracts of plants with allelopathic properties. Acta Bot. Bras. 27(1): 50-53. doi: 10.1590/S0102-33062013000100007. 
Bucci, S.J., Scholz, F.G., Goldstein, G., Meinzer, F.C., Franco, A.C., Zhang, Y., and YouHao, G. 2008. Water relations and hydraulic architecture in Cerrado trees: adjustments to seasonal changes in water availability and evaporative demand. Braz. J. Plant Physiol. 20(3): 233-245. http://dx.doi.org/10.1590/S1677-04202008000300007.

Carvalho, P.E.R. 2003. Espécies arbóreas brasileiras. Embrapa, Brasília.

Chaves, N., and Escudero, C. 1999. Variation of flavonoid syntheis induced by ecological factors. In Principles and Practices in Plant Ecology. Edited by Inderjit, K.M.M. Dakshini, and C.L. Foy. CRC Press, Boca Raton. pp. 267-285.

Chung, I.M., Ahn, J.K., and Yun, S.J. 2001. Assesment of allelopathic potential of barnyard grass (Echinochloa crus-galli) on rice (Oriza sativa L.) cultivars. Crop Prot. 20(10): 921928. doi: 10.1016/S0261-2194(01)00046-1.

Duke, S.O., Dayan, F.E., Rimando, A.M., and Ramafnani, J.G. 2000. Natural products as sources of herbicides: current status and future trends. Weed Res. 40: 499-505. doi: 10.1046/j.1365-3180.2000.00161.x.

Durigan, G., Bacic, M.C., Franco, G.A.D.C., and Siqueira, M.F. 1999. Inventário florístico do cerrado na Estação Ecológica de Assis, SP. Hoehnea 26: 149-172.

Eberlein, C.V. 1987. Germination of Sorghum almum seeds and longevity in soil. Weed Science 35(6): 796-801. Available from http://www.jstor.org/stable/4044573 [accessed 28 December 2014].

Eiten, G. 1972. The cerrado vegetation of Brazil. Bot. Rev. 38: 201-341.

Farias, A.C., Silva, A.J.R., and Tomassini, T.C.B. 1984. Constituents of Mochinea polymorpha. J. Nat. Prod. 47(2): 363-364. doi: 10.1021/np50032a021.

Ferreira, A.G., and Aquila, M.E.A. 2000. Alelopatia: uma área emergente da ecofisiologia. Braz. J. Plant Physiol. 12: 175-204. Available from http://www.cnpdia.embrapa.br/rbfv/v12ne.html [acessed 28 December 2014]. 
Franco, A.C. 2002. Ecophysiology of cerrado woody plants. In The cerrados of Brazil. Edited by P.S. Oliveira and R.J. Marquis. Columbia University Press, New York, pp. 178-197.

Fujii, Y., Parvez, S.S., Parvez, M.M., Ohmae, Y., and Iida, O. 2003. Screening of 239 medicinal plant species for allelopathic activity using the sandwich method. Weed Biol. Manag. 3: 233-241. doi: 10.1046/j.1444-6162.2003.00111.x.

Gatti, A.B., Perez, S.C.J.G.A., and Lima, M.I.S. 2004. Allelopathic activity of aqueous extracts of Aristolochia esperanzae O. Kuntze in the germination and growth of Lactuca sativa L. and Raphanus sativus L. Acta Bot. Bras. 18(3): 459-472. doi: 10.1590/S010233062004000300006 .

Gatti, A.B., Takao, L.K., Pereira, V.C., Ferreira, A.G., Lima, M.I.S., and Gualtieri, S.C.J. 2014. Seasonality effect on the allelopathy of Cerrado species. Braz. J. Biol. 74(Suppl. 3): 64(S)-69(S). doi: 10.1590/1519-6984.21512.

Gershenzon, J. 1984. Changes in the levels of plant secondary metabolites under water and nutrient stress. Recent Advances in Phytochemistry 18: 273-320. doi: 10.1007/978-14684-1206-2_10.

Gniazdowska, A., and Bogatek, R. 2005. Allelopathic interactions between plants. Multi site action of allelochemicals. Acta Physiol. Plant. 27(3): 395-407. doi: 10.1007/s11738-0050017-3.

Gobbo-Neto, L., and Lopes, N.P. 2007. Plantas medicinais: fatores de influência no conteúdo de metabólitos secundários. Quim. Nova 30(2): 374-381. Available from http://quimicanova.sbq.org.br/imagebank/pdf/Vol30No2_374_25-RV05289.pdf [accessed 28 December 2014].

González-Coloma, A., López-Balbosa, C., Santana, O., Reina, M., and Fraga, B.M. 2011. Triterpene-based plant defenses. Phytochem. Rev. 10(2): 245-260. doi: 10.1007/s11101010-9187-8. 
Gorla, C.M., and Perez, S.C.J.G.A. 1997. Influência de extratos aquosos de Miconia albicans Triana, Lantana camara L., Leucaena leucocephala(Lam) de Wit e Drimys winteri Forst, na germinação e crescimento de sementes de tomate e pepino. Rev. Bras. $\begin{array}{llll}\text { Sementes } & \text { 19: } & \text { 261-266. } & \text { Available }\end{array}$ http://www.abrates.org.br/revista/artigos/1997/v19n2/artigo19.pdf $\quad$ [Accessed 18 September 2015].

Gottsberger, G., and Silberbauer-Gottsberger, I. 2006. Life in the cerrado: origin, structure, dynamics and plant use. Reta Verlag, Ulm.

Hejl, A.M., and Koster, K.L. 2004. Juglone disrupts root plasma membrane $\mathrm{H}^{+}$-ATPase activity and impairs water uptake, root respiration, and growth in soybean (Glycine max) and corn (Zea mays). J. Chem. Ecol. 30(2): 453-471. doi: 10.1023/B:JOEC.0000017988.20530.d5. PMID: 15112735.

Hernández-Carlos, B., González-Coloma, A., Orozco-Valencia, Á.U., Ramírez-Mares, M.V., Andrés-Yeves, M.F., and Joseph-Nathan, P. 2011. Bioactive saponins from Microsechium helleri and Sicyos bulbosus. Phytochemistry 72: 743-751. doi:10.1016/j.phytochem.2011.02.022.

Hoffmann, W.A. 1996. The effects of cover and fire on seedling establishment in a Neotropical savanna. J. Ecol. 84: 383-393. doi:10.2307/2261200.

Horner, J.D. 1990. Nonlinear effects of water deficits on foliar tannin concentration. Biochem. Syst. Ecol. 18(4): 211-213. doi: 10.1016/0305-1978(90)90062-K.

Inoue, M., Nishimura, H., Li, H.-H., and Mizutani, J. 1992. Allelochemicals from Polygonum sachalinense FR. SCHM. (Polygonaceae). J. Chem. Ecol. 18(10): 1833-1840. doi: 10.1007/BF02751107.

Jung, S. 2004. Variation in antioxidant of young and mature leaves of Arabidopsis thaliana subjected to drought. Plant Science 166(2): 459-466. doi: 10.1016/j.plantsci.2003.10.012. 
Macías, F. A., Simonet, A. M., and Galindo, J.C.G. 1997. Bioactive steroids and triterpenes from Melilotus messanensis and their allelopathic potential. J. Chem. Ecol. 23(7): 17811803. doi: 10.1023/B:JOEC.0000006451.19649.a0.

Macías, F.A., Bastidas, A.O., Marín, D., Carrera, C., Chinchilla, N., and Molinillo, J.M.G. 2008. Plant biocommunicators: their phytotoxicity, degradation studies and potential use as herbicide models. Phytochem. Rev. 7(1): 179-194. doi: 10.1007/s11101-007-9062-4.

Marchaim, U., Werker, E., and Thomas, W.D.E. 1974. Changes in the anatomy of cotton seed coats caused by lucerne saponins. Bot. Gaz. 135(2): 139-146. doi: 10.1086/336742.

Martins, C.M., Vasconcellos, M.A.S., Rosseto, C.A.V., and Carvalho, M.G. 2010. Prospecção fitoquímica do arilo de sementes de maracujá amarelo e influência em germinação de sementes. Cienc. Rural 40(9): 1934-1940. doi: 10.1590/S0103-84782010000900013.

Matos, F.J.A. 1997. Introdução a fitoquímica experimental. Edições UFC, Fortaleza.

Mushtaq, N.M., Sunohara, Y., and Matsumoto, H. 2013. Allelochemical L-DOPA induces quinoprotein adducts and inhibits $\mathrm{NADH}$ dehydrogenase activity and root growth of cucumber. Plant Physiol. Biochem. 70: 374-378. doi: 10.1016/j.plaphy.2013.06.003.

Negrelle, R.R.B. 2011. Qualea Aubl. from Paraná State, Brazil. Acta Sci. 33(3): 347-355. doi: 10.4025/actascibiolsci.v33i3.3671.

Oliveira, A.K.M., Matias, R., Lopes, S.S., and Fontoura, F.M. 2014. Allelopathy and influence of leaves of Palicourea rigida (Rubiaceae) on seed germination and seedling formation in lettuce. Biosci. J. 30(5): 938-947. Available from $\underline{\text { http://www.seer.ufu.br/index.php/biosciencejournal/article/view/19842 }}$ [accessed 28 December 2014].

Peixoto, J.A., Silva, M.L.A., Crotti, A.E.M., Veneziani, R.C.S., Gimenez, V.M.M., Januario, A.H., Groppo, M., Magalhães, L.G., Santos, F.F., Alburquerque, S., Filho, A.A.S., and Cunha, W.R. 2011. Antileishmanial activity of the hydroalcoholic extract of Miconia 
langsdorffii, isolated compounds and semi-synthetic derivatives. Molecules 16: 18251833. doi:10.3390/molecules16021825.

Pinto, A.C., Silva, D.H.S., Bolzani, V.S., Lopes, N.P., and Epifanio, R.A. 2002. Produtos naturais: atualidade, desafios e perspectivas. Quim. Nova 25: 45-61. doi: 10.1590/S010040422002000800009.

Qian, H., Xu, X., Chen, W., Jiang, H., Jin, Y., Liu, W., and Fu, Z. 2009. Allelochemical stress causes oxidative damage and inhibition of photosynthesis in Chlorella vulgaris. Chemosphere 75(3): 368-375. doi: 10.1016/j.chemosphere.2008.12.040. PMID: 19171365.

Ranal, M.A., Santana, D.G., and Schiavini, I. 2010. Are there germination patterns for cerrado species? In Encyclopedia of life support systems. Tropical biology and conservation management, savannah ecosystems. Edited by K. Del-Claro, P.S. Oliveira, V. RicoGray, A.A.A. Barbosa, A. Bonet, F.R. Scarno, F.J.M. Garzón, M.V. Sampaio, M.R. Morris, N. Ramirez, O. Marçal Júnior, R.H.F. Macedo, R.J. Marquis, L. Coelho, R.P. Martins, S.C. Rodrigues \& U. Lüttge. UNESCO/EOLSS, Oxford. pp 106-159.

Rice, E. L. 1979. Allelopathy-an update. Bot. Rev. 45(1): 15-109. doi: 10.1007/BF02869951. Sannomiya, M., Cardoso, C.R.P., Figueiredo, M. E., Rodrigues, C.M., Santos, L.C., Santos, F.V., Serpeloni, J.M., Cólus, I.M., Vilegas, W., and Varanda, E.A. 2007. Mutagenic evaluation and chemical investigation of Byrsonima intermedia A. Juss. Leaf extracts. J. Ethnopharmacol. 112(2): 319-326. doi: 10.1016/j.jep.2007.03.014. PMID: 17459621.

Santana, D.G., and Ranal, M.A. 2000. Análise estatística na germinação. Braz. J. Plant $\begin{array}{llll}\text { Physiol. 12: 205-237. } & \text { Available } & \text { from }\end{array}$ http://www.cnpdia.embrapa.br/rbfv/pdfs/v12Especialp206.pdf $\quad$ accessed 27 October $2015]$. 
Santana, D.G., Ranal, M.A., Mustafa, P.C.V., and Silva, R.M.G. 2006. Germination measurements to evaluate allelopathic interactions. Allelopathy J. 17: 43-52.

Santos, R.C., Kushima, H., Rodrigues, C.M., Sannomiya, M., Rocha, L.R.M., Bauab, T.M., Tamashiro, J., Vilegas, W., and Hiruma-Lima, C.A. 2012. Byrsonima intermedia A. Juss.: gastric and duodenal anti-ulcer, antimicrobial and antidiarrheal effects in experimental rodent models. J. Ethnopharmacol. 140: 203-212. doi: 10.1016/j.jep.2011.12.008.

Sarmiento, G. 1996. Biodiversity and water relations in tropical savannas. In Biodiversity and savanna ecosystem processes. Edited by O.T. Solbrig, E. Medina and J.F. Silva. Springer Verlag, Berlin, pp. 61-75. http://dx.doi.org/10.1007/978-3-642-78969-4_4.

Scognamiglio, M., D’Abrosca, B., Fiumano, V., Chambery, A., Severino, V., Tsafantakis, N., Pacifico, S., Esposito, A., and Fiorentino, A. 2012. Oleanane saponins from Bellis sylvestris Cyr. and evaluation of their phytotoxicity on Aegilops geniculate Roth. Phytochemistry 84: 125-134. doi:10.1016/j.phytochem.2012.08.006.

Silva, D.A., Alves, V.G., Franco, D.M., Ribeiro, L.C., Souza, M.C., Kato, L., Carvalho, J.E., Kohn, L.K., Oliveira, C.M., and Silva, C.C. 2012. Antiproliferative activity of Luehea candicans Mart. et Zucc. (Tiliaceae). Nat. Prod. Res. 26(4): 364-369. doi: 10.1080/14786411003752102. PMID: 21432719.

Silva, E.R., Overbeck, G.E., and Soares, G.L.G. 2014. Phytotoxicity of volatiles from fresh and dry leaves of two Asteraceae shrubs: Evaluation of seasonal effects. S. Afr. J. Bot. 93: 14-18. doi: 10.1016/j.sajb.2014.03.006.

Silva, G.B., Martim, L., Silva, C.L., Young, M.C.M., and Ladeira, A.M. 2006. Potencial alelopático de espécies arbóreas nativas do Cerrado. Hoehnea 33(3): 331-338. Available from 
http://www.ambiente.sp.gov.br/institutodebotanica/files/2011/11/HOEHNEA 33(3) T T 0 4.pdf [accessed 28 December 2014].

Silvestre, D.M., Kolb, R.M., Frei, F., and Santos, C. 2013. Phytotoxicity of organic extracts of Turnera ulmifolia L. and Turnera diffusa Willd. ex Schult. in cucumber seeds. Acta Bot. $\begin{array}{llll}\text { Bras. } & 27: & 476-482 . & \text { Available }\end{array}$ http://www.scielo.br/readcube/epdf.php?doi=10.1590/S010233062013000300003\&pid=S 0102-33062013000300003\&pdf path=abb/v27n3/v27n3a03.pdf\&lang=en [accessed 19 June 2015].

Stefanello, M.E.A., Cervi, A.C., Wisniewski, A., and Simionatto, E.L. 2006. Óleo essencial de Gochnatia polymorpha (Less) Cabr. ssp floccosa Cabr. Quim. Nova 29(5): 999-1002. http://dx.doi.org/10.1590/S0100-40422006000500021.

Taiz, L., and Zeiger, E. 2009. Plant physiology. Sinauer Associates, Sunderland.

Villela, F.A., Doni Filho, L., and Sequeira, E.L. 1991. Tabela de potencial osmótico em função da concentração de polietileno glicol 6.000 e da temperatura. Pesqui. Agropecu. $\begin{array}{llllll}\text { Bras. } & \text { 26(11/12): } & 1957 & - & 1968 . & \text { Available }\end{array}$ http://seer.sct.embrapa.br/index.php/pab/article/download/3549/882 $\quad$ [accessed 28 December 2014].

Voll, E., Brighenti, A.M., Gazziero, D.L.P., and Adegas, F.S. 2003. Relationships between weed seed species germination and electrical conductivity use. Planta Daninha 21(2): 181-189. doi: 10.1590/S0100-83582003000200003.

Waller, G.R., Yang, C.F., Chen, L.F., Su, C.H., Liou, R.M., Wu, S.C., Young, C.C., Lee, M.R., Lee, J.S., Cheng, C.S., Chou, C.H., and Kim, D. 1999. Saponins produced during the life cycle of mungbeans and their role as allelochemicals. In Studies in plant science, vol. 6: advances in plant glycosides, chemistry and biology. Edited by C.-R. Yang, and O. Tanaka. Elsevier Science B.V., Amsterdam, pp. 105-130. 
Wardle, D.A., Nicholson, K.S., and Ahmed, M. 1992. Comparison of osmotic and allelopathic effects of grass leaf extract on grass seed germination and radicle elongation. Plant Soil 140: 315-319. 
Table 1. Yield and physical-chemical characteristics of leaf extracts of Cerrado species obtained during the dry and rainy season.

\begin{tabular}{clcc}
\hline \multirow{2}{*}{ Parameter } & Extracts & \multicolumn{2}{c}{ Season } \\
\cline { 3 - 4 } & Byrsonima intermedia & 0.016 & Rainy \\
\hline Yield & Gochnatia polymorpha & 0.012 & 0.011 \\
$(\mathrm{~g} / \mathrm{mL})$ & Luehea candicans & 0.005 & 0.007 \\
& Miconia chamissois & 0.019 & 0.008 \\
& Qualea cordata & 0.012 & 0.012 \\
& & & \\
& Byrsonima intermedia & 4.72 & 4.906 \\
$\mathrm{pH}$ & Gochnatia polymorpha & 5.59 & 6.22 \\
& Luehea candicans & 5.47 & 5.75 \\
& Miconia chamissois & 3.93 & 4.48 \\
& Qualea cordata & 3.69 & 4.09 \\
& & & \\
& Byrsonima intermedia & -0.025 & -0.022 \\
Osmotic potential & Gochnatia polymorpha & -0.008 & -0.008 \\
$(\mathrm{MPa})$ & Luehea candicans & -0.011 & -0.011 \\
& Miconia chamissois & -0.031 & -0.008 \\
& Qualea cordata & -0.025 & -0.011 \\
\hline
\end{tabular}


Table 2. Effect of seasonality on the phytotoxicity of leaf extracts of the studied species on the germination of maize and cucumber. Data are presented as the mean percentage difference compared with the negative control $(=100 \%) \pm$ standard deviation. Absolute values for the negative control of maize: $\mathrm{G}=94.00 \pm 6.52 \%, \mathrm{~V}=0.02 \pm 0.00 \mathrm{~h}^{-1}$, and $\mathrm{U}=1.66 \pm 0.12$ bits. Absolute values for the negative control of cucumber: $\mathrm{G}=$ $99.00 \pm 2.24 \%, \mathrm{~V}=0.03 \pm 0.00 \mathrm{~h}^{-1}$, and $\mathrm{U}=1.34 \pm 0.27$ bits.

\begin{tabular}{|c|c|c|c|c|c|}
\hline \multirow{2}{*}{ Parameter } & \multirow{2}{*}{ Extract } & \multicolumn{2}{|c|}{ Maize } & \multicolumn{2}{|c|}{ Cucumber } \\
\hline & & Dry season & Rainy season & Dry season & Rainy season \\
\hline \multirow{5}{*}{$\mathrm{G}(\%)$} & Byrsonima intermedia & $-6.0 \pm 5.7(\mathrm{ab})$ & $-11.0 \pm 11.9(a b c)$ & $-1.0 \pm 4.5(\mathrm{ab})$ & $-3.0 \pm 4.5(a b)$ \\
\hline & Gochnatia polymorpha & $-26.0 \pm 22.8(a b c)$ & $-36.0 \pm 11.5\left(b c^{*}\right)$ & $-1.0 \pm 4.5(\mathrm{ab})$ & $-4.0 \pm 4.2(\mathrm{ab})$ \\
\hline & Luehea candicans & $0.0 \pm 2.2(\mathrm{a})$ & $-42.0 \pm 31.9\left(\mathrm{c}^{*}\right)$ & $1.0 \pm 0.0(\mathrm{ab})$ & $-7.0 \pm 8.9\left(\mathrm{~b}^{*}\right)$ \\
\hline & Miconia chamissois & $-2.0 \pm 6.1(\mathrm{a})$ & $-8.0 \pm 8.9(a b)$ & $3.0 \pm 2.2(\mathrm{a})$ & $-2.0 \pm 2.7(a b)$ \\
\hline & Qualea cordata & $-14.0 \pm 12.9(\mathrm{abc})$ & $-8.0 \pm 8.2(a b)$ & $-5.0 \pm 5.0(a b)$ & $0.0 \pm 0.0(\mathrm{ab})$ \\
\hline \multirow{5}{*}{$\mathrm{V}(\%)$} & Byrsonima intermedia & $-12.8 \pm 8.1(\mathrm{abc})$ & $-4.9 \pm 4.6(\mathrm{abc})$ & $-17.1 \pm 5.6\left(\mathrm{abcd}^{*}\right)$ & $-30.1 \pm 5.2\left(\mathrm{~d}^{*}\right)$ \\
\hline & Gochnatia polymorpha & $-18.4 \pm 10.3(a b d)$ & $-19.8 \pm 6.3\left(b^{*}\right)$ & $-6.2 \pm 8.2(\mathrm{a})$ & $-23.2 \pm 8.7\left(\mathrm{bcd}^{*}\right)$ \\
\hline & Luehea candicans & $1.4 \pm 8.4\left(\mathrm{c}^{*}\right)$ & $-8.3 \pm 9.1(\mathrm{abc})$ & $-8.9 \pm 12.5(a b)$ & $-26.1 \pm 9.3\left(\mathrm{~cd}^{*}\right)$ \\
\hline & Miconia chamissois & $-18.8 \pm 3.7(\mathrm{abd})$ & $-3.7 \pm 4.3(\mathrm{ac})$ & $-13.4 \pm 6.3(\mathrm{abc})$ & $-19.2 \pm 6.5($ abcd $*)$ \\
\hline & Qualea cordata & $-32.3 \pm 9.5(\mathrm{~d})$ & $-9.0 \pm 7.5(a b c)$ & $-18.2 \pm 6.5(\mathrm{abcd})$ & $-10.8 \pm 5.6(a b c)$ \\
\hline \multirow{5}{*}{$\mathrm{U}(\%)$} & Byrsonima intermedia & $29.8 \pm 12.8$ & $-6.9 \pm 7.7$ & $23.7 \pm 14.1$ & $68.0 \pm 32.4\left(^{*}\right)$ \\
\hline & Gochnatia polymorpha & $14.8 \pm 17.2$ & $16.9 \pm 19.0$ & $57.4 \pm 57.5$ & $51.8 \pm 27.1$ \\
\hline & Luehea candicans & $28.9 \pm 23.9$ & $-23.1 \pm 46.5$ & $63.7 \pm 49.3$ & $60.4 \pm 21.7(*)$ \\
\hline & Miconia chamissois & $55.3 \pm 27.5$ & $32.4 \pm 12.4$ & $32.4 \pm 7.9$ & $24.5 \pm 3.9$ \\
\hline & Qualea cordata & $52.0 \pm 33.4$ & $4.5 \pm 26.2$ & $58.0 \pm 22.3$ & $17.6 \pm 17.3$ \\
\hline
\end{tabular}

Note: G - germinability, V - speed of germination, U - synchronism. *Significant difference between the negative control and the treated according to ANOVA and Dunnett's test. Significant differences among treatments for maize or cucumber are indicated by different letters according to factorial MANOVA and Tukey's test for the interaction between factors $(\mathrm{p}<0.05)$. All statistical tests were performed on absolute values. 
Table 3. Effect of seasonality on the phytotoxicity of leaf extracts of the studied species on growth of maize and cucumber seedlings. Data are presented as the mean percentage difference compared with the negative control $(=100 \%) \pm$ standard deviation. Absolute values for the negative control of maize: main root length $=3.89 \pm 0.90 \mathrm{~cm}$, shoot length $=1.30 \pm 0.33 \mathrm{~cm}$, and secondary roots number $=3.18 \pm 0.44$. Absolute values for the negative control of cucumber: main root length $=8.64 \pm 1.67 \mathrm{~cm}$, shoot length $=2.05 \pm 0.32 \mathrm{~cm}$, and secondary roots number $=17.38 \pm 3.81$.

\begin{tabular}{|c|c|c|c|c|c|}
\hline \multirow{2}{*}{ Parameter } & \multirow{2}{*}{ Extract } & \multicolumn{2}{|c|}{ Maize } & \multicolumn{2}{|c|}{ Cucumber } \\
\hline & & Dry season & Rainy season & Dry season & Rainy season \\
\hline \multirow{5}{*}{$\begin{array}{l}\text { Main root } \\
\text { length } \\
(\%)\end{array}$} & Byrsonima intermedia & $-71.1 \pm 15.8\left(\mathrm{a}^{*}\right)$ & $-66.4 \pm 19.3\left(a b^{*}\right)$ & $-93.1 \pm 2.5\left(\mathrm{a}^{*}\right)$ & $-94.4 \pm 3.5\left(\mathrm{a}^{*}\right)$ \\
\hline & Gochnatia polymorpha & $-51.7 \pm 12.8\left(\mathrm{bd}^{*}\right)$ & $-12.0 \pm 17.2\left(\mathrm{c}^{*}\right)$ & $-71.5 \pm 11.1\left(\mathrm{e}^{*}\right)$ & $-42.3 \pm 11.9\left(\mathrm{~d}^{*}\right)$ \\
\hline & Luehea candicans & $78.3 \pm 39.4(\mathrm{e})$ & $27.4 \pm 34.2\left(f^{*}\right)$ & $-57.5 \pm 12.5\left(b^{*}\right)$ & $-63.2 \pm 8.0\left(\mathrm{c}^{*}\right)$ \\
\hline & Miconia chamissois & $-62.5 \pm 19.9\left(a b^{*}\right)$ & $-14.0 \pm 37.4\left(\mathrm{c}^{*}\right)$ & $-90.9 \pm 5.3\left(a^{*}\right)$ & $-58.7 \pm 10.7\left(b^{*}\right)$ \\
\hline & Qualea cordata & $-69.0 \pm 12.7\left(\mathrm{a}^{*}\right)$ & $-39.0 \pm 27.2\left(d^{*}\right)$ & $-93.2 \pm 3.1\left(\mathrm{a}^{*}\right)$ & $-93.4 \pm 2.9\left(\mathrm{a}^{*}\right)$ \\
\hline \multirow{5}{*}{$\begin{array}{c}\text { Shoot length } \\
(\%)\end{array}$} & Byrsonima intermedia & $-19.4 \pm 19.4(\mathrm{cf})$ & $20.1 \pm 22.3(b)$ & $-21.4 \pm 23.0\left(b c^{*}\right)$ & $-48.3 \pm 22.2\left(\mathrm{de}^{*}\right)$ \\
\hline & Gochnatia polymorpha & $-2.0 \pm 24.4\left(e f^{*}\right)$ & $11.7 \pm 17.6(\mathrm{be})$ & $-21.1 \pm 25.4\left(b c^{*}\right)$ & $41.6 \pm 39.1\left(\mathrm{f}^{*}\right)$ \\
\hline & Luehea candicans & $52.2 \pm 47.2\left(\mathrm{a}^{*}\right)$ & $40.9 \pm 39.1(\mathrm{ad})$ & $6.6 \pm 43.3$ (a) & $-5.1 \pm 34.5(\mathrm{ab})$ \\
\hline & Miconia chamissois & $-22.0 \pm 20.0(\mathrm{c})$ & $57.0 \pm 26.5\left(\mathrm{a}^{*}\right)$ & $-61.4 \pm 8.5\left(\mathrm{~d}^{*}\right)$ & $-2.0 \pm 18.9(\mathrm{a})$ \\
\hline & Qualea cordata & $-29.1 \pm 18.2(\mathrm{c})$ & $27.6 \pm 29.7(\mathrm{bd})$ & $-56.7 \pm 15.7\left(\mathrm{~d}^{*}\right)$ & $-36.9 \pm 16.2\left(\mathrm{ce}^{*}\right)$ \\
\hline \multirow{5}{*}{$\begin{array}{l}\text { Secondary } \\
\text { roots } \\
\text { number }(\%)\end{array}$} & Byrsonima intermedia & $-34.9 \pm 45.8\left(d^{*}\right)$ & $-6.0 \pm 41.8\left(b c^{*}\right)$ & $-71.3 \pm 14.4\left(b d^{*}\right)$ & $-65.9 \pm 17.9\left(\mathrm{~d}^{*}\right)$ \\
\hline & Gochnatia polymorpha & $-11.2 \pm 26.0(\mathrm{c})$ & $7.6 \pm 23.9(\mathrm{abc})$ & $-40.4 \pm 20.1\left(\mathrm{a}^{*}\right)$ & $-39.4 \pm 16.2\left(\mathrm{a}^{*}\right)$ \\
\hline & Luehea candicans & $24.1 \pm 23.1(\mathrm{a})$ & $18.8 \pm 19.2$ (a) & $-33.8 \pm 16.3\left(a^{*}\right)$ & $-41.1 \pm 13.6\left(\mathrm{a}^{*}\right)$ \\
\hline & Miconia chamissois & $-57.3 \pm 42.9\left(\mathrm{e}^{*}\right)$ & $19.6 \pm 19.6(a)$ & $-84.3 \pm 15.4\left(\mathrm{c}^{*}\right)$ & $0.0 \pm 22.7\left(\mathrm{e}^{*}\right)$ \\
\hline & Qualea cordata & $-44.7 \pm 40.1\left(\mathrm{de}^{*}\right)$ & $9.8 \pm 32.1(\mathrm{ab})$ & $-77.1 \pm 13.1\left(b^{*}\right)$ & $-79.3 \pm 17.9\left(b^{*}\right)$ \\
\hline
\end{tabular}

Note: *Significant difference between the negative control and the treated according to ANOVA and Dunnett's test. Significant differences among treatments for maize or cucumber are indicated by different letters according to factorial MANOVA and Tukey's test for the interaction between factors $(\mathrm{p}<0.05)$. All statistical tests were performed on absolute values. 
Table 4. Phytochemical screening of leaf extracts of Byrsonima intermedia (EB), Gochnatia polymorpha (EG), Luehea candicans (EL), Miconia chamissois (EM) and Qualea cordata (EQ) obtained during the dry season (DS) and the rainy season (RS).

\begin{tabular}{lccccccccccc}
\hline \multirow{2}{*}{ Chemical test } & \multicolumn{3}{c}{ EB } & \multicolumn{3}{c}{ EG } & \multicolumn{3}{c}{ EL } & \multicolumn{3}{c}{ EM } & \multicolumn{2}{c}{ EQ } \\
\cline { 2 - 10 } & DS & RS & DS & RS & DS & RS & DS & RS & DS & RS \\
\hline Alkaloids* & - & - & - & - & - & - & - & - & - & - \\
Anthraquinones & + & - & ++ & + & - & - & + & ++ & - & + \\
Coumarins & - & - & - & - & - & - & - & - & - & - \\
Steroids & - & - & - & - & - & - & - & - & - & - \\
Triterpenoids & ++ & + & ++ & + & + & ++ & + & + & + & ++ \\
Flavonoids & - & - & - & - & - & - & - & - & - & - \\
Saponins & - & ++ & + & + & ++ & ++ & + & - & ++ & + \\
Tannins & ++ & + & - & - & + & + & ++ & + & ++ & + \\
\hline
\end{tabular}

Note: "_“ represents a negative test (absence of characteristic colours, precipitate (for the tannin test) or spume (for the saponins test), “+” represents a weakly positive test (the presence of characteristic and soft colours, precipitate (for the tannin test) or spume (for the saponins test) paucity), and “++" represents a strongly positive test (the presence of characteristic and striking colours, precipitate (for the tannin test) or spume (for the saponins test) in abundance). *Tested using the reagents of Dragendorff, Hager and Mayer. 